YEARBOOK

of ANTITRUST

and REGULATORY

STUDIES

www.yars.wz.uw.edu.pl
Peer-reviewed scientific periodical, focusing on legal and economic issues of antitrust and regulation. Creative Commons Attribution-No Derivative Works 3.0 Poland License.

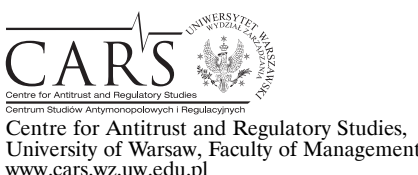

www.cars.wZ.uw.edu.pl

\title{
Private Antitrust Enforcement: A New Era for Collective Redress?
}

\author{
by
}

\section{Sofia Oliveira Pais*}

\section{CONTENTS}

I. Introduction

II. The European Recommendation 2013/396/EU of 11 June 2013

1. General remarks

2. Opt-in vs. opt-out models

3. Funding

4. Cross-border mass disputes

III. The new Belgian and British laws on consumer collective redress

IV. The experience of collective redress in Portugal: the Popular Action

V. Conclusions

\section{Abstract}

It will be argued in this article that the EU Recommendation on common principles for collective redress might have limited impact on the field of competition law due to: several uncertainties regarding the legal standing in class actions; difficulties in their funding; and the risk of forum shopping with cross-border actions. Nevertheless, Belgium and Great Britain have recently introduced class actions into their national legal systems and addressed some of the difficulties which other Member States were experiencing already. It will also be suggested that the Portuguese model - the 'Popular Action' - and recent Portuguese practice may be considered an interesting example to follow in order to overcome some of the identified obstacles to private antitrust enforcement.

* Professor of Law, Faculty of Law, Catholic University of Portugal, Jean Monnet Chair, Researcher and Coordinator of the Católica Research Centre for the Future of Law (Porto, Portugal); e-mail: sofiaopais@gmail.com. 


\section{Résumé}

Dans cet article nous soutenons l'avis que la Recommandation de l'Union européenne relative à des principes communs applicables aux mécanismes de recours collectif pourrait avoir un impact limité sur le domaine du droit de la concurrence, en raison de plusieurs incertitudes concernant la qualité à agir dans l'action de groupe, les difficultés de leur financement et le risque de forum shopping dans le cas des actions transfrontalières. Néanmoins, la Belgique et le RoyaumeUni ont récemment introduit dans leurs lois nationales des actions de groupes et ont répondu aux certaines difficultés qui étaient déjà vécue par d'autres États membres. Nous soutenons aussi l'avis que le modèle portugais - Action Populaire - et la pratique récente des actions collectives au Portugal, peuvent être considérés comme des exemples intéressants à suivre afin de surmonter certains obstacles à l'application privée du droit de la concurrence.

Key words: Recommendation 2013/396/EU; collective redress mechanisms; legal standing; funding; forum shopping; popular action.

JEL: K23; K42.

\section{Introduction}

The European Parliament and the Council adopted on 26 November 2014 a Directive on certain rules governing actions for damages under national law for infringements of the competition law ${ }^{1}$ (hereafter, Damages Directive), which might have significant impact in the 28 Member States even if the EU is still far from US experiences where private antitrust enforcement represents more than $90 \%$ of all antitrust cases ${ }^{2}$. Even so, with the introduction of the new Directive, another step has been taken in order to increase the relevance of private antitrust enforcement as a complementary tool to its public enforcement ${ }^{3}$, which

${ }^{1}$ Directive 2014/104/EU of the European Parliament and of the Council of 26 November 2014 on certain rules governing actions for damages under national law for infringements of the competition law provisions of the Member States and of the European Union (OJ L 349, 05.12.2014, p. 1).

${ }^{2}$ See R.H. Lande, 'Benefits of private enforcement: empirical background' [in:] A. Foer, J. Cuneo (eds.), The International Handbook on Private Enforcement of Competition Law, Edward Elgar Publishing, 2012, p. 34.

3 The Directive will not be addressed here which nevertheless be welcomed as a significant milestone to achieving a more effective enforcement of EU antitrust rules: by giving victims apparently easier access to evidence and more time to make their claims, but also by preserving the attractiveness of leniency and settlement programmes. 
still plays the lead in the EU ${ }^{4}$. Yet the Directive does not require Member States to introduce collective redress mechanisms for the enforcement of Articles 101 and 102 TFEU, even if both Member States and consumers recognize that collective redress is a necessary solution in this context. In fact, a recent survey by Eurobarometer shows that almost $80 \%$ of European consumers would be more willing to go to court if collective redress procedures were available (because they would not have to carry the risk and litigation costs alone $)^{5}$. This survey confirms also the explanation given by the European Court of Human Rights (hereafter, ECHR) in Gorraiz Lizarraga and others v. Spain witch stated that 'in modern-day societies, when citizens are confronted with particularly complex administrative decisions, recourse to collective bodies such as associations is one of the accessible means, sometimes the only means available to them whereby they can defend their particular interests effectively'6. On the other hand, several Member States have recently introduced class actions into their national laws, confirming the urgent need for such mechanisms for effective private enforcement of competition law.

In the EU, the problem of collective redress was addressed with non-binding acts - a fact that may limit the success of such solutions. These included the European Commission Recommendation 2013/396/EU of 11 June 2013 on common principles for injunctive and compensatory collective redress mechanism in the Member States, concerning violations of rights granted under Union $\mathrm{Law}^{7}$ (hereafter, Recommendation). The Recommendation was accompanied by a Communication to the European Parliament and the Council 'Towards a European Horizontal Framework for Collective Redress's. According to the European Commission (hereafter, EC or Commission), EU Member States should implement the principles set forth in this Recommendation into their national collective redress systems by 26 July $2015^{9}$. On the basis of information and data that must be provided by Member

4 Another alternative to private enforcement is public compensation. According to Ezrachi and Ioannidou, public compensation 'would enable competition authorities to award a certain form of compensation alongside the imposed fine following a public investigation'. Public compensation in the course of public investigation could, therefore, facilitate compensation, increase deterrence and encourage greater consumer involvement. The authors sustain that public compensation should be considered as another remedy (in addition to fines) and should be formalized. Cf. A. Ezrachi, M. Ioannidou, 'Public Compensation as a Complementary Mechanism to Damages Actions: From Policy Justifications to Formal Implementation' (2012) 3(6) Journal of European Competition Law \& Practice 536-537.

5 Flash Eurobarometer 299, Consumer Attitudes Towards Cross-Border Trade and Consumer Protection, http://ec.europa.eu/public_opinion/flash/fl_299_en.pdf (accessed 8 April 2014).

6 Cf. Gorraiz Lizarraga and others v. Spain, App no 62543/00, ECHR 2004-III, para. 38.

7 OJ L 201, 26.07.2013, p. 60 (hereafter, the Recommendation).

8 COM (2013) 401/2.

${ }^{9}$ Recommendation, point 38. 
States, the EC will assess the implementation of the Recommendation by 26 July 2017 at the latest ${ }^{10}$.

The Recommendation applies not only to collective redress mechanisms in consumer law but also to procedures in a wide variety of EU law fields, including competition and environmental laws as well as data protection and financial services. The Recommendation is applicable to both judicial and out-of-court collective redress measures which should be fair, equitable, timely and not excessively expensive. Its aim is to promote an efficient justice system that will contribute to European growth ${ }^{11}$.

This article will focus mainly on antitrust class actions before courts, highlighting some of the gaps and difficulties in the implementation of the principles mentioned in the Recommendation. Furthermore, it will be shown that a new era in collective redress is arising with the recent introduction of new rules on class actions in some national legal systems. It will be suggested finally that Portuguese experiences in this domain might be relevant to other Member States also.

\section{The European Recommendation 2013/396/EU of 11 June 2013}

\section{General remarks}

The Recommendation 'aims to ensure a coherent horizontal approach to collective redress in the European Union without harmonising Member States systems', improving access to justice while ensuring appropriate procedural guarantees to avoid abusive litigation ${ }^{12}$. As Vice-President Viviane Reding explained: 'Member States have very different legal traditions in collective redress and the Commission wants to respect these. Our initiative aims to bring more coherence when EU law is at stake'13.

10 Recommendation, point 41.

11 Translated into an economic perspective, this means the increase of European social welfare, 'including consumer and producer surplus'; cf. G. Barker, B.P. Freyens, 'The Economics of European Commission's Recommendation on Collective Redress' [in:] E. Lein, D. Fairgrieve, M. Otero Crespo, V. Smith (eds.), Collective Redress in Europe - Why and How?, British Institute of International and Comparative Law 2015, p. 5.

12 Recommendation; cf. http://europa.eu/rapid/press-release_IP-13-524_en.htm. Collective redress is a 'procedural mechanism that allows, for reasons of procedural economy and/or efficiency of enforcement, many similar claims to be bundled into a single court action'. Cf. COM (2013) 401 final, para. 12.

13 Ibidem. 
At the end of the public consultation process launched in 2011, and in light of the 2012 resolution of the European Parliament ${ }^{14}$, the EC was well aware of the risk of abuses involving class actions seen on the other side of the Atlantic ${ }^{15}$. The solutions adopted in the Recommendation reflect such knowledge and try to avoid that risk, overcoming Member States' opposition regarding collective redress, particularly the opt-out model ${ }^{16}$. Even so, several difficulties and uncertainties remain. It will be shown that the main problems lie in the apparent ineffectiveness of the opt-in model; encumbrances in the implementation of due process guarantees (such as the right to be heard and the adequate representation of the group); difficulties to fund class actions and; uncertainties in cross-border mass claims. Member States must thus still face the challenge of finding reasonable solutions to these problems while achieving the right balance between an effective system (that facilitates access to justice in antitrust cases regarding low value damages claims) and the need to avoid speculative claims.

\section{Opt-in vs. opt-out models}

One of the main concerns in collective redress relates to the legal standing necessary to bring a collective action. In the opt-out model, the resulting court decision is binding on everyone that did not opt-out. This solution can increase the effectiveness of this mechanism as it overcomes the passive nature of victims of antitrust infringement as well as the fact that antitrust claims are usually of small value (a fact that discourages access to courts in light of the hard work and large legal expenses involved ${ }^{17}$ ).

Nevertheless, the Commission favours the opt-in model where the judgement is only binding for those who opted-in. The EC argues that this

14 Cf. COM SEC (2011) 173 and the Resolution of the European Parliament of 2 February 2012, 2011/2089 (INI).

15 The solution to set aside the US model was also sustained by several authors; see, for instance, L.A. Willet, 'U.S. Style Class Actions in Europe: A Growing Threat' (2005) 9(6) Briefly 9. On the other hand, refusing the view that the USA model leads necessarily to abuses cf. I. Tzankova, D. Hensler, 'Collective Settlements in the Netherlands: Some Empirical Observations' [in:] A. Stadler, C. Hodges (eds.), Resolving Mass Disputes: ADR and Settlement of Mass Claims, Edward Elgar, 2013, p. $91 \mathrm{ff}$.

${ }^{16}$ It has been suggested that, in France, the principle 'nul ne plaide par procureur' (no one shall plead by proxy) is part of the concept of 'ordre public' and would prevent the opt-out model; cf. E. Werlauff, 'Class Action and Class Settlement in a European Perspective' (2013) 24 European Business Law Review 177.

17 Providing a detailed analysis of this issue, cf. S.O. Pais, A. Piszcz, 'Package on Actions for Damages Based on Breaches of EU Competition Rules: Can One Size Fit All?' (2014) 7(10) YARS 209. 
solution is compatible with the legal traditions of EU Member States, for instance the Italian solution ${ }^{18}$, it avoids litigation abuses and respects the freedom of potential claimants whether to take part in the action or not ${ }^{19}$. In fact, the principle of party disposition, which is the right to bring an action before the court as well as to end it, still underlies the procedural traditions of most civil laws in EU member States. Opt-out proceedings should thus only be allowed when Member States can prove that they are superior to the opt-in model (justified by 'reasons of sound administration of justice'20), namely for claims which are not expected to be fulfilled in individual proceedings because of their small amount ${ }^{21}$.

Although the concerns of the EC should be considered relevant, other safeguards can be introduced at national level in order to avoid abusive litigation. Establishing the notion of a 'preliminary assessment' of the claim by national judges, or introducing the 'loser pays' principle, are among the solutions that will be shown to clearly reduce obstacles to collective redress mechanisms in competition procedures.

On the other hand, existing Member States' experiences show that the opt-in model is not very effective. The JJB Sports case 22 provides a paradigmatic example here which involved the Consumer Organizations 'Which?' that brought a class action on behalf of 130 individual consumers, despite the fact that it was estimated that two million consumers were actually affected by the contested practice. The same is true for the UCF Que Choisir case ${ }^{23}$ that concerns a follow-on action brought forward by a French consumer association claiming damages from a cartel involving three mobile operators. The French Competition Authority estimated in its own investigation that the cartel could have had a negative impact on almost 20 million consumers, but only around

18 In Italy, Article 140-bis of the Consumer Code allows opt-in class actions, which provide for a 'preliminary judicial filter': an action will be declared inadmissible when (i) it is clearly unfounded; (ii) the plaintiff has a conflict of interest; (iii) the interests are not identical or similar; (iv) the plaintiff is not able to adequately protect the interests of the class. On this topic, cf. C. Tesauro, D. Ruggiero, 'Private Damage Actions Related to European Competition Law in Italy' (2010) 1(6) Journal of European Competition Law \& Practice 514-521.

19 EC, White Paper on Damages Actions for Breach of the EC antitrust rules, COM (2008) 165, 2.4.2008; see also Commission Staff Working Paper, SEC (2008) 404, 2.4.2008 (hereafter, Commission Staff Working Paper).

${ }^{20}$ Recommendation, point 21.

21 Cf. D. Panagiotis, L. Tzakas, 'Effective Collective Redress in Antitrust and Consumer Protection Matters: a Panacea or a Chimera?' (2011) 48 Common Market Law Review 1125.

22 Price-fixing of replica football kit (Case CP/0871/01), OFT Decision CA98/06/2003 of 1 August 2003.

23 Cited by P. Buccirossi, M. Carpagnano, 'Is it Time for the European Union to Legislate in the Field of Collective Redress in Antitrust (and how)?' (2013) 4(1) Journal of European Competition Law \& Practice 5. 
12,000 consumers joined the private action. The choice of the opt-in model should, therefore, be reconsidered at least in 2017 when the Recommendation is due for review.

Another matter that needs clarification concerns due process guarantees such as legal standing in representative actions and the right of victims to be heard, particularly in the opt-out model. In certain types of collective actions (such as group actions), the action can be brought jointly by those who claim to have suffered harm. However, in the case of a representative action, the Recommendation states that the legal standing to bring such an action should be limited to ad hoc certified entities, designated representative entities which fulfil certain legal criteria, or to public authorities. The question is: which criteria? Should legal standing be conferred only to consumer organizations? What about foreign representative entities? Should they have legal standing?

Although the Recommendation does not answer all those questions, it refers to certain conditions that the representative entity should meet: '(a) a representative entity should have a non-profit making character; (b) there should be a direct relationship between the main objectives of the entity and the rights granted under Union law that are claimed to have been violated in respect of which the action is brought; and (c) the entity should have sufficient capacity in terms of financial resources, human resources, and legal expertise, to represent multiple claimants acting in their best interest' ${ }^{24}$.

It has been discussed whether these requirements apply to ad hoc certified foreign representative entities, as they are not clearly mentioned in the text of the Recommendation. In fact, it has been argued that points 4 and 6 of the Recommendation distinguish between 'entities which have been officially designated in advance' and 'entities which have been certified on an ad hoc basis by a Member State's national authorities or courts for a particular representative action' and for cross-border situations. Still, point 18 of the Recommendation only considers the first type ${ }^{25}$. Does this mean that entities certified on an ad hoc basis for a particular representative action in one Member State cannot act in another State? Taking into account the spirit of the Recommendation and the need to assure efficient collective redress mechanisms, ad hoc certified foreign representative entities should also have legal standing 26 .

${ }^{24}$ Recommendation, recitals 17, 18, 21 and point 63

25 Cf. Statement of the European Law Institute on Collective Redress and Competition Damages Claims (hereafter, Statement ELI), at p. 15; http://www.europeanlawinstitute. eu/fileadmin/user_upload/p_eli/Projects/S-5-2014_Statement_on_Collective_Redress_and_ Competition_Damages_Claims.pdf (access 01.05.2015).

26 Ad hoc certification of representative entities in the context of class actions might also require, as it has been pointed out, 'training programmes' for judges who will be deciding on those claims, cf. Statement ELI, p. 15-16. 
Finally, as far as the right to be heard in the opt-out model is concerned, dissemination of information is considered vital to avoid the risk of individuals being bound by the court decision without being aware of it. Problems arise when the identity of the victims is not known and notification is not possible. In the Netherlands, for instance, it is the Court of Appeal of Amsterdam that is competent to approve group settlements in this kind of actions and it makes significant efforts to ensure that potential victims are informed of class actions. In the Shell case, for example, '110,000 letters in 22 languages were sent to shareholders in 105 countries, and announcements were made via 44 newspapers throughout the world' 27 . A problem arises in situations where a personal notice (by post or email) is not possible because victims are unknown or costs thereof are excessive. It has been suggested that a national or European registration system for class actions should be implemented as it could contribute to solving this issue ${ }^{28}$. The problem here is that this reasonable solution does not yet exist, be it in all Member States or at the European level. For the time being, national courts should thus have the discretion to fix other solutions to ensure that an individual is aware of his/ her possibility to opt-out.

\section{Funding}

Funding is another key problem of class actions. In these types of actions, the value of the individual claims is usually low, while access to courts is expensive and time consuming. It is a priority to find solutions to the issue of how to fund such actions, besides the use of the victims' own resources. One of the interesting choices here is the creation of special funds, either through the use of crowdfunding 'based on the solicitation of multiple voluntary contributions of small amounts' ${ }^{29}$, or through donations from successful litigants to fund future class actions.

It has also been proposed to use State resources in this context, such as state legal aid. The problem with public resources, particularly considering the 2008 financial crisis, is that they are usually very limited and will only address people with very limited (or without) resources of their own. As a matter of fact, national requirements concerning the use of legal aid are strict,

27 R. Hermans, J. de Bie Leuveling Tjeenk, 'International Class Action Settlements in the Netherlands since Converium' [in:] The International Comparative Legal Guide to Class \& Group Actions 2015, p. 5, cf. http://www.debrauw.com/wp-content/uploads/NEWS\%20-\%20 PUBLICATIONS/ICLG-Class-Action-15-Chapter-2.pdf (access 31.08.2015).

28 Point 35 of the Recommendation. Cf. Statement ELI, p. 16.

${ }^{29}$ Ibidem. 
and usually do not apply to Small and Medium Sized Enterprises (hereafter, SMEs) and to cross-border claims ${ }^{30}$.

An alternative solution might be the use of lawyers' contingency fees (which include preparation of the claim, representation in court and gathering of evidence; those fees are calculated as a \% of the awarded compensation). Yet the EC does not support this option, and neither does a meaningful number of Member States who fear the risk of abusive and frivolous claims as well as the risk of conflicting interests of lawyers and their clients (for instance, whether or not to settle more quickly for a lower amount) ${ }^{31}$. Actually, according to the Recommendation: 'The Member States should ensure that the lawyers' remuneration and the method by which it is calculated do not create any incentive to litigation that is unnecessary from the point of view of the interest of any of the parties'32 and 'Member States that exceptionally allow for contingency fees should provide for appropriate national regulation of those fees in collective redress cases, taking into account in particular the right to full compensation of the members of the claimant party'33. Although the risk of abusive claims should not be underestimated, it can be reduced with the 'loser pays' rule that exists in an important number of Member States. Avoiding contingency fees, as suggested by the EC, can thus represent a potentially significant barrier to full compensation. Contingency fees should, therefore, be considered a useful solution, provided certain safeguards are also introduced.

Third party funding is another solution worth noting despite the fact that the Recommendation does not clarify this concept and only requires that funding-entities do not influence procedural decisions or settlements. Third party funding is usually considered to be a practice where a $3^{\text {rd }}$ party (not a party to the actual proceedings) offers financial support to a claimant in order to cover his/her litigation expenses. The $3^{\text {rd }}$ party receives in return a given $\%$ of the victim's indemnity if the claim is successful, or nothing if the case is lost. As it has been pointed out, "the logic is similar to the US-style contingency fee scheme, except that the funds come from a third party and not from the plaintiff's lawyer', allowing the victim to file the claim and, in turn, improving access to justice as well as the deterrence effect ${ }^{34}$. Several

30 Cf. Statement ELI, p. 33.

31 P.T. Hurst, 'Thoughts on the American rule and contingency fees' (2012) 2 European Business Law Review 35.

32 Recommendation, points 29, 30.

33 Recommendation, point 30.

34 M. Morpurgo,'A Comparative Legal and Economic Approach to Third-Party Litigation Funding', (2011) 19 Cardozo Journal of International and Comparative Law 343, apud O. Cojo Manuel, 'Third-Party Litigation Funding: Current State of Affairs and Prospects for Its Further Development in Spain' (2014) 3 European Review of Private Law, 441, 443. 
doubts arise, however, concerning the frontiers of this concept. For instance, which litigation decisions can be taken by the 'funders' without turning the funder agreement into an assignment agreement? ${ }^{35}$ Should insurance for legal expenses (before the event) be included in the concept? ${ }^{36}$ What about individual member contributions or donations?

This is not the place to study in detail all of these situations. However, it is important to stress that the key element of the $3^{\text {rd }}$ party funding concept should be that the latter does not own the claim and it is not a 'party' to the actual proceeding, and may lie with the court fixing the guidelines on this issue ${ }^{37}$.

\section{Cross border mass disputes}

The Recommendation suggests that Member States should ensure that where cross-border mass disputes emerge 'a single collective action in a single forum is not prevented by national rules on admissibility or standing of the foreign groups of claimants or the representative entities originating from other national legal systems ${ }^{38}$. Therefore, it is possible that parallel actions against the same infringer on behalf of different groups of victims may emerge in courts of different Member States. However, the risk of forum shopping (and it is interesting to compare the solutions of the

35 See, however, the 'Austrian model of group litigation' (an opt-in model) where potential claimants assign their claims to a consumer association; cf. Statement ELI, p. 6.

36 Insurance for legal expenses must take into account the Eshig case, C-199/08, ECR I-82, 95 which concerns an Austrian national who, together with thousands of other investors, invested money in companies which became insolvent, and sought an assurance from UNIQA to cover legal expenses taken by lawyers chosen by him. The Court of Justice ruled that Article 4(1)(a) of Council Directive 87/344/EEC of 22 June 1987 (on the coordination of laws, regulations and administrative provisions relating to legal expenses insurance) must be interpreted as not permitting the legal expenses insurer to reserve to itself the right to select the legal representative of all the insured persons concerned, where a large number of insured persons suffer losses, as a result of the same event (no. 70). With this decision, insurers may choose to exclude those actions from their insurance or may try to force settlements in order to swiftly end the case.

${ }^{37}$ In addition, for cases of private $3^{\text {rd }}$ party funding of compensatory collective redress, the Recommendation says that it is prohibited 'to base remuneration given to or interest charged by the fund provider on the amount of the settlement reached or the compensation awarded unless that funding arrangement is regulated by a public authority to ensure the interests of the parties' (point 32). Importantly however, the assignment of claims is not easily allowed in all Member States (hereafter, MSs) (in fact, 'funder becomes owner of the claims and the action is no longer representative'; cf. Statement ELI, at p. 56 and http://www.justiz.nrw.de/ nrwe/lgs/duesseldorf/lg_duesseldorf/j2013/37_O_200_09_Kart_U_Urteil_20131217.html (access 01.06.2015).

38 Recommendation, point 17. 
Recommendation with those of the Injunction Directive ${ }^{39}$, as it has been pointed out $)^{40}$ and parallel actions have not been addressed by EU institutions yet. For instance, can Article 6 of the Brussels I Regulation ${ }^{41}$ be applied, which allows claimants to sue several defendants in the Member States (as long as claims are closely connected and there is a risk of conflicting decisions), to the situation where several victims intend to sue the same defendant? What about the risk of conflicting decisions in the case of parallel actions? Or the

39 Directive 98/27/EC of the European Parliament and of the Council of 19 May 1998 on injunctions for the protection of consumers' interests, OJ L 166, 11.6.1998, p. 51. To discuss the Directive, see I. Benöhr, 'Collective Redress in the Field of European Consumer Law' (2014) 41(3) Legal Issues of Economic Integration 248. In the beginning, only traditional areas were covered by the Directive such as consumer law, travel packages and contracts negotiated away from business premises, and certain practices such as unfair terms and misleading advertising. However, sale of consumer goods and associated guarantees, electronic commerce, distance marketing of consumer financial services, and unfair business-to-consumer commercial practices in the internal market were also included in 2009 with Directive 2009/22/EC of 23 April 2009 on injunctions for the protection of consumers' interests (OJ L 110, 010.5.2009, p. 30). The Directive may lead to the prohibition of an infringement and the imposition of fines, but it does not allow the award of damages. As already mentioned, this issue was addressed in the Consumer Policy strategy of 2007-2013 and the EC (DG SANCO) launched a public consultation on collective consumer redress which led to the Green Paper on Consumer Collective Redress (2008). In 2011, DG Competition, DG SANCO and DG Justice issued a joint consultation paper on collective redress which produced the European Parliament Resolution of 2012 and the Recommendation of 2013.

40 As it has already been explained - Statement ELI, p. 37 - according to article 4 of the Injunctive Directive, each Member State shall take the necessary measures to ensure that, in the event of an infringement originating in that Member State, any qualified entity from another Member State where the interests protected by that qualified entity are affected by the infringement, may seize the court or administrative authority referred to in Article 2, on presentation of the list provided for in paragraph 3; while point 18 of the Recommendation invites MSs to accept the legal standing of foreign representative entities in other circumstances: if in a cross-border mass claims, the infringement has its origin in one MS (normally the place where the infringer is domiciled) but causes harm to consumers in other MSs, the Recommendation asks all MSs, having jurisdiction over the case to accept the legal standing of particular representative entities from other MSs. This solution favours forum shopping. Claimants will search which jurisdiction offers better instruments of collective redress such as out of court settlements binding (as it happens in Dutch law).

41 Council Regulation (EC) 44/2001 of 22 December 2000 on jurisdiction and the recognition and enforcement of judgments in civil and commercial matters, OJ L 12, 16.01.2001, p. 1, recasted with Regulation 1215/2012/EU of the Parliament and of the Council of 12.12.2012 on jurisdiction and the recognition and enforcement of judgements in civil and commercial matters, which entered into force on 01.01.2015, OJ L 351, 20.12.2012, p. 1 (hereafter, Brussels I Recast Regulation). With this Regulation, the geographical scope of Section 4 of Chapter I changed. Under Regulation 44/2001, that section applied only if the defendant was domiciled in a MS; according to Regulation 1215/2012/EU the section is applicable regardless of the defendant's domicile. The aim is to ensure protection for EU consumers. 
risk of overcompensation (multiple recoveries of the same harm)? A specific solutions for anticompetitive practices causing damages in the territories of different States needed?

In the absence of specific rules for class actions concerning antitrust infringements, in tort cases if victims suffer damages in different States and at a different time, only the court of the defendant or the court where the harmful event occurred ${ }^{42}$ will have jurisdiction to decide the case ${ }^{43}$. Moreover, the court must have jurisdiction over all the absent claimants.

The Amsterdam Court of Appeal applied Article 6(1) (now Article 8(1) of the Brussels I Recast Regulation) to establish Dutch jurisdiction over foreign tort victims who do not reside in the Netherlands; it is sufficient that one of the 'interested parties' resides there. This approach, as well as the use of Article 5(1) (now Article 7(1) of the Brussels I Recast Regulation) by the Dutch court, has, however, been criticized particularly due to the preclusive effect of settlement under Dutch WCAM proceedings ${ }^{44}$.

It has been argued that Brussels I Regulation is not adequate to solve the problems of collective redress ${ }^{45}$ (it was mainly conceived for two-party proceedings), or at least that specific solutions should be built into the existing legal framework ${ }^{46}$. On the other hand, it has also been suggested ${ }^{47}$ to apply the law of the defendant's domicile or the law of the Member State where the majority of victims reside, in other words, to apply the "principle of the

42 That is to say, the place where the 'illegal' act was committed or the place of injury or damage.

43 Articles 2 and 5 of Regulation Brussels I 44/2001 (now articles 4 and 7(2), Brussels I Recast Regulation).

44 As A. Stadler mentions, cf. 'The Commission's Recommendation on Common Principles of Collective Redress and Private International Law' [in:] E. Lein, D. Fairgrieve, M. Otero Crespo, V. Smith (eds.), op. cit., p. 242-246, the Dutch law (WCAM) allows the parties to negotiate an out-of-court settlement and, if the Amsterdam court approves the settlement, 'interested parties' (liable party and representative entity) will be legally bound and cannot sue the liable party, which can be problematic in the opt-out model.

45 B. Hess, 'Cross-border Collective Litigation and the Regulation Brussels I' (2010) 30 Praxis Des Internationalen Private Und Verfahrensrechts (Iprax) 116.

46 Tzakas (supra note 21 at 1163) argues that 'the group plaintiffs or the represented claims must be accurately defined in order to avoid multiple recoveries of the same harm, and (...) lis pendens should apply to the extent that a potential for irreconcilable rulings is present'.

47 Green Paper - Damages actions for breach of the EC antitrust rules \{SEC(2005) 1732\} / COM/2005/0672 final. The EC suggests that 'the applicable law should be determined by the general rule (...) that is to say with reference to the place where the damage occurs' (option 31 ); and 'that there should be a specific rule for damages claims based on an infringement of antitrust law. This rule should clarify that for this type of claims, the general rule (...) shall mean that the laws of the States on whose market the victim is affected by the anti-competitive practice could govern the claim' (option 32). 
centre of gravity (which also raises several doubts in itself) ${ }^{48}$. Additionally, the EC proposed a system of national registers for collective redress either at national or European level ${ }^{49}$, to address, among others, the problems of parallel proceedings and irreconcilable judgements.

\section{The new Belgian and British laws on consumer collective redress}

Despite some of the uncertainties still surrounding the Recommendation, several Member States have adopted domestic legislation to introduce (or improve) collective redress mechanisms. Particularly interesting are some of the solutions found in recent Belgian and British laws.

The Belgian Law of 28 March $2014^{50}$ (hereafter, Belgian Law) entered into force in September 2014. It introduces a new section into the Economic Law Code entitled 'Actions for collective redress' which intends to enhance and enforce the rights of consumers. The new Belgian Law allows the parties (or the judge, if the parties cannot agree) to choose between the opt-in and the opt-out solution (the opt-in model is mandatory to those that do not reside in Belgium, or if the collective action seeks to redress moral or bodily harm). These class actions make it possible to aggregate individual consumer complaints in order to be dealt with in a single court proceeding; its aim is to obtain compensation for losses (although a claim cannot be brought against public authorities or non-profit organisations) and the judgement has res judicata effects on all members of the group.

Class actions can only be brought by a limited group of representatives: (1) the Federal Ombudsman; (2) a consumer organization represented in the 'Conseil de la Consommation' recognized by the Minister of Economic Affairs; (3) an association recognised by the Minister, with legal personality for at least three years, which has a corporate purpose directly related to the collective prejudice suffered by a group of consumers, and which does not pursue a sustainable economic purpose.

48 B. Aňoveros Terradasas argues that it would be difficult to choose the criteria for identifying the centre of gravity and it could, again, discriminate consumers whose domiciles have not been chosen; cf. 'Consumer Collective Redress under the Brussels I Regulation Recast in the Light of the Commission's Common Principles' (2015) 11(2) Journal of Private International Law 143-162.

49 Recommendation, point 35.

${ }^{50} \mathrm{Cf}$. http://www.collectiveredress.org/collective-redress/reports/belgium/overview (access 01.04.2015). 
Regarding the procedures, the national court may play a fundamental role here. In fact, the new Belgian Law establishes a two-stage procedure (admissibility of the petition and negotiation). If no settlement agreement is reached between the parties, or no settlement agreement was confirmed by the court (and the court can refuse the agreement if the compensation for the group is unreasonable, or if the indemnity exceeds the real costs), then the proceedings continue on the merits. If the judge decides that the application for collective redress is successful, a claims administrator will be appointed for the execution of the final judgement (only lawyers, ministerial civil servants and holders of a judicial mandate can fulfil that role). The Court will check the execution of the decision and if the claims administrator is not able to pay the full amount of the compensation to the consumers, the Court has discretion to decide on the distribution of the funds.

Unfortunately, the new Belgian Law has no rules on $3^{\text {rd }}$ party funding and the principle is that the representative entity will support the financial risk of the procedure. The Belgian government argued, albeit not in a convincing manner, that the choice to grant standing only to selected organizations guided by the collective interest that they represent, would overcome hesitations to bring forwards claims. As it has already been suggested, the $3^{\text {rd }}$ party funding option, or similar solutions, must be considered or 'the law is thus clearly not meeting the requirements of the Recommendation' regarding the funding of collective actions ${ }^{51}$.

Another recent reform regarding class actions took place in Britain in the form of the UK Consumer Rights Act of 26 March 2015 (hereafter, CRA) ${ }^{52}$, which is expected to come into force on 1 October 2015. It amends the Competition Act of 1998 gathering in one place consumer rights covering contracts for the supply of goods, services, digital content and the law relating to unfair terms in consumer contracts; it also deals with consumer collective actions for anti-competitive behaviour.

The aim of the CRA is to empower consumers and SMEs to challenge anticompetitive behaviour through the Competition Appeal Tribunal (hereafter, CAT), in addition to the clarification of other issues ${ }^{53}$. The CAT will be able to adjudicate not only follow-on actions but also stand-alone actions. The

51 J.T. Novak, 'The new Belgian law on consumer collective redress and compliance with EU law requirements' [in:] E. Lein, D. Fairgrieve, M. Otero Crespo, V. Smith (eds.), op. cit., 196.

52 Cf. http://www.legislation.gov.uk/ukpga/2015/15/notes/division/2 (access 01.04.2015).

53 It (1) consolidates enforcers' powers as listed in Schedule 5 to investigate potential breaches of consumer law; (2) gives civil courts and public enforcers greater flexibility to take the most appropriate action for consumers when dealing with breaches of consumer law; (3) imposes a duty on letting agents to publish their fees and other information; (4) expands the list of higher education providers which are required to join the higher education complaints handling scheme. 
new British law will, therefore, introduce a new 'opt-out' class action before the CAT, making it easier for private parties (SMEs and consumers) to bring damages actions for competition law breaches. As such, it will implement changes suggested by the Department for Business, Innovation \& Skill ${ }^{54}$ which conducted in 2012 a consultation on options for reform concerning private actions in competition law. From now on, claimants will not need to specify the regime, as it is for the CAT to decide whether the action will follow the opt-in or the opt-out solution. On the other hand, to avoid abuses, the CRA prohibits contingency fees and exemplary damages in collective actions and applies the 'loser pays' rule ${ }^{55}$.

British Civil Procedure Rules provide for representative actions in rule 19.6 whereby a claim can be brought by a representative entity when more than one person has the same interest in the claim. However, the opt-out class action model was set aside in the Emerald Supplies case where the High Court held that it was not possible to determine the 'same interest' until the question of liability had been tried ${ }^{56}$.

On the other hand, according to Section 47B of the British Competition Act of 1998, only certain bodies (such as consumer organizations) could, until the recent amendment, bring such claims and they had to identify the individual consumers being represented. These solutions proved to be time consuming, expensive, and ineffective as the famous JJB Sports ${ }^{57}$ case shows where the Consumer Organization 'Which?' brought a class action on behalf of about 130 consumers. At the same time, it was estimated that two million consumers were actually affected by the infringement and that they incurred losses amounting to 50 million pounds. The case ended with a settlement whereby the infringer paid 20 pounds to each victim who joined the suit, and 10 pounds to all future victims who would appear within one year of the compromise.

The CRA of 2015 modified Section 47B so that other representative entities (but not law firms) besides consumer organizations or individual class members may now bring claims collectively as long as they raise the same, similar or

${ }^{54}$ Cf. https://www.gov.uk/government/consultations/private-actions-in-competition-law-aconsultation-on-options-for-reform (access 01.04.2015)

55 The English rule according to which the loser pays all litigation costs apparently prevails over the American rule, that is to say, each party supports its own costs; cf. O. Cojo Manuel, op. cit., p. 439-468. On the other hand, there are several statutory exceptions to the US rule; in fact, English 'loser pays' rule was included in tort reform legislation proposed by the Bush Administration in 1992; for more details on the Common Benefit Doctrine, cf. P.T. Hurst, 'Thoughts on the American rule and contingency fees' (2012) European Business Law Review 27.

56 Emerald Supplied Limited v. British Airways [2010] EWCA Civ. 1284.

57 Price-fixing of replica football kit (Case CP/0871/01) OFT Decision CA98/06/2003 of 1 August 2003. 
related issues of fact or law. Therefore, claims can be brought on behalf of a defined group without having to identify each individual claimant. An opt-out collective action would cover all class members except those who opted out (and any class member who is not domiciled in the UK at the specified time and who has not opted in). Awarded damages that remain unclaimed will go to a prescribed charity, or to the class representative for costs in connection with the proceedings.

In addition, the CRA of 2015 introduces a collective settlement procedure - representative entities may settle a case prior to bringing the claim before the CAT, as long as the terms of the settlement are 'just and reasonable'. It also provides a redress scheme - the Competition and Markets Authority can authorise voluntary redress schemes where the level of the fine can be reduced if the competition law infringer offers compensation.

This CRA of 2015 is considered a significant step forward on the road to effective private enforcement in the $\mathrm{UK}^{58}$, with safeguards being observed with a strong judicial review process (regarding the departure of certain points from the EU Recommendation, namely preliminary merits test, an assessment of the adequacy of the representative entity and whether class action is the best solution). Nevertheless, uncertainties remain such as those regarding the funding of such actions. Therefore, it is important to take into account the experiences obtained in this field in other countries such as Portugal.

\section{The experience of collective redress in Portugal: the Popular Action}

In Portugal, there are no specific rules for actions for damages from antitrust infringements besides the Portuguese Competition Law (Law 19/2012, 8 May), general substantive and procedural rules established in the Portuguese Civil Code $^{59}$, and its Code of Civil Procedure.

In case of an antitrust infringement, the plaintiff may complain to the Portuguese Competition Authority and its decision can be reviewed by the Competition, Regulation and Supervision Court (and subsequently by the Lisbon Court of Appeal). The plaintiff can also complain to a civil court and ask for the compensation of damages and/or challenge the validity of an agreement through common declaratory actions or (more rarely) through

58 A. Nikpay, D. Taylor, 'The New UK Competition Regime: Radically Different or More of the Same?' (2014) 5 Journal of European Competition Law \& Practice 278, 285.

59 Particularly Articles 483 (tort liability) and 562 (damages award). 
collective actions (the decision can be reviewed by the Court of Appeal and subsequently by the Supreme Court).

As there are no specific rules for antitrust damages actions, this means that both direct and indirect purchasers may have standing. Courts can request the disclosure of documents considered relevant from the parties, opposing parties or $3^{\text {rd }}$ persons; refusal to comply with such request could lead to a fine and even reverse the burden of proof. Moreover, the judge may also order the production of evidence in order to find the truth, as well as require expert evidence, such as an assessment of quantitative damages and a clarification of the economic issues at stake - the probative value of such evidence is decided by the judge ${ }^{60}$.

Concerning collective redress, Portugal has an opt-out system called 'Ação Popular' (Popular Action; hereafter, PA) ${ }^{61}$. It is mentioned in Article 52(2) of the Portuguese Constitution which establishes: 'Everyone shall be granted the right of popular actions, to include the right to apply for the adequate compensation for an aggrieved party or parties, in such cases and under such terms as the law may determine, either personally or via associations that purport to defend the interests in question. That right shall be exercised namely to (...) promote the prevention, cessation or judicial prosecution of offences against public health, consumer rights, the quality of life or the preservation of environment and the cultural heritage'. Damages from antitrust infringements can be compensated through the PA since the list of interests mentioned in Article 1 is only exemplary and the Portuguese Supreme Court did not refuse that solution in its decision of 7 October 2003. This right was implemented through Law 83/95 of 31 August 1995 (Popular Action Act; hereafter, PAA), which establishes certain special procedural rules such as: 'it is up to the judge's own initiative to collect evidence and [the judge] is not bound by the initiatives of the parties' (Article 17), and even 'if a particular appeal has no suspensive effect,

60 This kind of request was recently made in the Portuguese Sport TV case; the Portuguese Court of Competition, Regulation and Supervision confirmed, on 4 June 2014, the decision of the PCA (although reducing the fine), condemning Sport TV for the abuse of its dominant position in the conditional access market for channels with premium sports content.

61 On this topic, see H.S. Antunes, 'Class Actions, Group Litigation and Other Forms of Collective Litigation (Portuguese Report)' (2009) 622 The Annals of the American Academy of Political and Social Science 161; S.O. Pais, 'A união faz a força? Breves reflexões sobre os mecanismos colectivos de reparação no contexto da aplicação privada do direito da concorrência da União' [in:] Liber Amicorum em Homenagem ao Professor Doutor Mota Campos, Coimbra editora 2013, p. 873; S.O. Pais, 'Entre clemência e responsabilidade - Uma história de sucesso? - Ac. do Tribunal de Justiça (Grande Secção), de 14 de Junho de 2011, Proc. C-360/09’ (2012) 37 Cadernos de Direito Privado 1; L. Rossi, M. Sousa Ferro, 'Private enforcement of competition law in Portugal (II): Actio Populari - Facts, fictions and dreams' (2013) IV(13) Revista de Concorrência e Regulação, 35. 
in general terms, the judge may, in a class action, give that effect, to prevent damage irreparable or difficult to repair' (Article 18) ${ }^{62}$.

According to Articles 2, 3 and 16 PAA, standing to initiate a PA is granted to: a) any citizen (and it has been argued that this reference can include foreigners) ${ }^{63}$; b) any legal association or foundation (a legal entity whose powers include the interests covered by the PA, which is not engaged in any type of professional business competing with companies or liberal professionals); c) to local authorities (concerning the interests of all those who are residing in the area) and, finally: d) to the public prosecutor's office, which may replace the claimants if the contested behaviour endangers the interests involved. While SMEs cannot seek compensation directly, they can do so through the aforementioned types of claimants referred to in the PAA. If the action is not dismissed by the judge during its preliminary assessment, the claimants will represent all of the holders of rights or interests who suffered the given antitrust damage and did not opt-out. This rule can be excluded by the court considering the circumstances of the case (for instance, if the representation was inadequate $)^{64}$.

62 There are other opt-out models used in the EU such as the Dutch model, which is usually also considered 'economically and legally' interesting; cf. K. Purnhagen, 'United We Stand, Divided We Fall? Collective Redress in the EU from the Perspective of Insurance Law' (2013) 1 European Review of Private Law 500. In fact, the Dutch law has three mechanisms of collective action: (1) the collective action of art. 3:305 BW (Dutch Civil Code) which allows a foundation or association to obtain an injunction, but it does not allow the award of damages; (2) legal entity or individual claimants represent the victims (individual mandates) and this action allows the award of damages; (3) extrajudicial negotiations by representative entities may lead to a settlement which the court may consider binding to all those that have not opted out (WCAM Procedure). Furthermore, the Dutch Act on Collective Settlement of Mass Damage Claims (WCAM) also allows foreign applicants in the proceedings (a foreign representative organization can participate, so long as it has legal standing) and every victim who is included in one of the categories of the settlement and did not opt-out in time is bound by that settlement, including foreign parties, which happened for instance in the Converium case. Cf. H. Van Lith, The Dutch Collective Settlements Act and Private International Law, Rotterdam 2010, p. 26, available at http://ec.europa.eu/competition/consultations/2011_collective_redress/saw_annex_en.pdf. On these topics, see also the Danish solution; cf. the Danish Competition Act, consolidated Act no. 23 of 17 January 2013, as amended by Section 1 in Act no. 620 of 12 June 2013 and Section 22 in Act no. 639 of 12 June 2013, http://en.kfst.dk/Competition/ /media/KFST/English\%20 kfstdk/Competition/Legislation/Engelsk\%20udgave\%20af\%20lovbekendtgoerelse $\% 207002013$. pdf. (access 01.04.2015).

63 Cf. M.T. de Sousa, A Legitimidade Popular na Tutela dos Interesses Difusos, Lex, Lisboa 2003, p. 178.

64 Settlement agreements in the popular action must be checked by the court (and its assessment should include the adequacy of the representative entity), see M. Teixeira de Sousa, op. cit., p. 247. 
Regarding financial expenses, the PAA establishes that the claimant is exempt from the payment of the costs if the application is at least partially granted; if the claim is totally unsuccessful, the claimant will be obliged to pay an amount fixed by the judge, between $10 \%$ and $50 \%$ of the costs that would be normally payable, taking into account the claimant's financial situation and the formal or substantive reason for the dismissal (Article 20). Contingency fees are not allowed as the Portuguese Bar Association Statute prohibits quota litis. At the same time, however, $3^{\text {rd }}$ party funding is not prohibited ${ }^{65}$ and the role played by the Public Prosecutor may prevent abuses in this regard.

On the other hand, the court may have to fix compensation for the infringement of the interests of those not individually identified (Article 22(2) PAA). The right to damages shall be extinguished within three years from the final judgement that has recognized the damage and the unclaimed funds shall be delivered to the Ministry of Justice. The latter will create a special account and allocate the payment to attorney fees and to support access to the courts (Article 22(4)-(5) PAA). The PAA does not explicitly provide for specific entities to distribute the total compensation among the injured parties. In antitrust cases, consumer associations (or similar entities) should be considered the most appropriate to receive and manage the indemnities. Indeed, this solution is one of those suggested in the Commission Staff Working White Paper: the distribution of unclaimed funds should be directed to a public interest foundation or via "cy-pres" distribution, that is, 'damages awarded are not distributed directly to those injured to compensate for the harm they suffered (for instance because they cannot be identified) but are rather used to achieve a result which is as near as it may be (e.g. damages attributed to a fund protecting consumers' interests in general) ${ }^{\prime 66}$.

The Portuguese Consumer Association, DECO, has already successfully used the PA to seek compensation for consumers in the famous DECO v. Portugal Telecom Case. The parties arrived here at a settlement amounting to 120 million EUR, paid by Portugal Telecom to its clients through free national calls provided during a certain period of time ${ }^{67}$.

Recently also, on 12 March 2015, the Portuguese Competition Observatory, a non-profit association of academics from several Portuguese universities, filed a mass damages claim against Sport $\mathrm{TV}^{68}$. The latter had a dominant

65 Ibidem, p. 247.

${ }^{66}$ Point 47 of the Commission Staff Working Paper.

67 The Supreme Court decided the case in 2003; cf. Supreme Court Decision - Portuguese Consumer Protection Association (DECO) v. Portugal Telecom, 7.10.2003, Case 03 A1243, http:// www.dgsi.pt/jstj.nsf/954f0ce6ad9dd8b980256b5f003fa814/1db6e4a1a7cadeed80256de5005292d4 ?OpenDocument (access 10.02.2015).

68 Lisbon Judicial Court, case no. 7074/15.8T8LSB. 
position in two relevant products/services markets: the (wholesale) domestic market of conditional access channels with premium sports content (upstream), and in the (retail) market of subscription television (downstream).

In 2013, the Portuguese Competition Authority (hereafter, PCA) imposed a fine of 3.7 million EUR upon Sport TV for applying a discriminatory remuneration system in distribution agreements for Sport TV's television channels (abuse took place from 1 January 2005 to 31 March 2011). The PCA's decision concluded an investigation launched in 2010, following a complaint by the operator of subscription-based television services Cabovisão - Televisão por Cabo S.A. Sport TV had implemented a remuneration system that involved the systematic application of discriminatory conditions to pay-TV operators for equivalent services; imposing unfair transaction conditions; placing other operators at a competitive disadvantage in the market for pay-TV; limiting the production, distribution, technical development and investment for the services in question; abusing its dominant position in the market for premium sports channels to the detriment of competition and end-users. Sport TV was condemned by the PCA and the decision was upheld (in part) by both Portuguese courts. In fact, although the Competition, Regulation and Supervision Court (specialized Portuguese court of first instance for competition matters) had reduced the fine from 3.7 to 2.7 million EUR, it upheld (in part) the PCA decision. In the judgement delivered on 11 March 2015, the Lisbon Court of Appeal confirmed that Sport TV abused its dominance by applying discriminatory conditions to subscription-based television operators, at the same time dismissing the appeal filed by Sport TV. The next day, on 12 March 2015, a class action was submitted against Sport TV by the Portuguese Competition Observatory. The action seeks 'to compensate over 600,000 clients for damages allegedly resulting from a number of anticompetitive practices, but also to compensate those who were excluded from the benefit of these channels due to the inflation of prices and all Portuguese pay-tv subscribers, between 2005 and June 2013 (over 3 million at the end of the period), who suffered from a reduction of competition on this market' ${ }^{69}$.

To sum up, the Portuguese collective redress system may be considered as an interesting example to be followed by other European countries as it has the added value of giving standing to any injured consumer or consumer association. Moreover, court fees are not meaningful (they might even not exist), the public prosecutor may replace the claimant if the latter decides to withdraw from the suit, and the judge can collect evidence on his own initiative. Finally, judicial checks are available during several phases of the proceedings, providing safeguards to avoid abusive class actions.

69 M.S. Ferro, 'Collective Redress: Will Portugal Show the Way?' (2015) Journal of European Competition Law \& Practice 1-2. 


\section{Conclusions}

The recent reforms in Belgium and Britain suggest a new era for collective redress. On the one hand, the introduction of opt-out systems, not only in the two above laws but also in other Member States such as Portugal for instance, should be considered a duly justified departure from the option proposed by the European Commission in its Recommendation. Taking into account the positive effects of the opt-out system in national laws, provided it is accompanied by the necessary safeguards (such as judicial checks in several phases of the proceedings), it represents a meaningful step towards a more effective collective redress system. On the other hand, although funding of collective actions is still a major issue, Member States' laws rarely address this concern and ignore the need to adapt certain traditional solutions. In this context, the prohibition of contingency fees should be reconsidered and a reduction of the amount payable for court fees should be provided, as is the case in Portugal.

\section{Literature}

Aňoveros Terradasas B., 'Consumer Collective Redress under the Brussels I Regulation Recast in the Light of the Commission's Common Principles' (2015) 11(2) Journal of Private International Law.

Antunes H.S., 'Class Actions, Group Litigation and Other Forms of Collective Litigation (Portuguese Report)' (2009) 622 The Annals of the American Academy of Political and Social Science.

Barker G., Freyens B.P., ‘The Economics of European Commission's Recommendation on Collective Redress' [in:] E. Lein, D. Fairgrieve, M. Otero Crespo, V. Smith (eds.), Collective Redress in Europe - Why and How?, British Institute of International and Comparative Law 2015.

Buccirossi P., Carpagnano M., 'Is it Time for the European Union to Legislate in the Field of Collective Redress in Antitrust (and how)?' (2013) 4(1) Journal of European Competition Law \& Practice.

Cojo Manuel O., 'Third-Party Litigation Funding: Current State of Affairs and Prospects for Its Further Development in Spain' (2014) 3 European Review of Private Law.

Ezrachi A., Ioannidou M., 'Public Compensation as a Complementary Mechanism to Damages Actions: From Policy Justifications to Formal Implementation' (2012) 3(6) Journal of European Competition Law \& Practice.

Ferro M.S., 'Collective Redress: Will Portugal Show the Way?' (2015) Journal of European Competition Law \& Practice.

Hess B., 'Cross-border Collective Litigation and the Regulation Brussels I' (2010) 30 Praxis Des Internationalen Private Und Verfahrensrechts (Iprax). 
Hurst P.T., 'Thoughts on the American rule and contingency fees' (2012) 2 European Business Law Review.

Lande R.H., 'Benefits of private enforcement: empirical background' [in:] A. Foer, J. Cuneo (eds.), The International Handbook on Private Enforcement of Competition Law, Edward Elgar Publishing, 2012.

Nikpay A., Taylor D., 'The New UK Competition Regime: Radically Different or More of the Same?' (2014) 5 Journal of European Competition Law \& Practice.

Novak J.T., 'The new Belgian law on consumer collective redress and compliance with EU law requirements' [in:] E. Lein, D. Fairgrieve, M. Otero Crespo, V. Smith (eds.), Collective Redress in Europe - Why and How?, British Institute of International and Comparative Law 2015.

Panagiotis D., Tzakas L., 'Effective Collective Redress in Antitrust and Consumer Protection Matters: a Panacea or a Chimera?' (2011) 48 Common Market Law Review.

Pais S.O., 'Entre clemência e responsabilidade - Uma história de sucesso? - Ac. do Tribunal de Justiça (Grande Secção), de 14 de Junho de 2011, Proc. C-360/09’ (2012) 37 Cadernos de Direito Privado.

Pais S.O., 'A união faz a força? Breves reflexões sobre os mecanismos colectivos de reparação no contexto da aplicação privada do direito da concorrência da União' [in:] Liber Amicorum em Homenagem ao Professor Doutor Mota Campos, Coimbra editora 2013.

Pais S.O., Piszcz A., 'Package on Actions for Damages Based on Breaches of EU Competition Rules: Can One Size Fit All?' (2014) 7(10) YARS.

Rossi L., Ferro M.S., 'Private enforcement of competition law in Portugal (II): Actio Populari - Facts, fictions and dreams' (2013) IV(13) Revista de Concorrência e Regulação.

de Sousa M.T., A Legitimidade Popular na Tutela dos Interesses Difusos, Lex, Lisboa 2003.

Stadler A., 'The Commission's Recommendation on Common Principles of Collective Redress and Private International Law' [in:] E. Lein, D. Fairgrieve, M. Otero Crespo, V. Smith (eds.), Collective Redress in Europe - Why and How?, British Institute of International and Comparative Law 2015.

Tesauro C., Ruggiero D., 'Private Damage Actions Related to European Competition Law in Italy' (2010) 1(6) Journal of European Competition Law \& Practice.

Tzankova I., Hensler D., 'Collective Settlements in the Netherlands: Some Empirical Observations' [in:] A. Stadler, C. Hodges (eds.), Resolving Mass Disputes: ADR and Settlement of Mass Claims, Edward Elgar 2013.

Werlauff E., 'Class Action and Class Settlement in a European Perspective' (2013) 24 European Business Law Review.

Willet L.A., 'U.S. Style Class Actions in Europe: A Growing Threat' (2005) 9(6) Briefly. 